\title{
THE EFFECT OF ACIDIFICATION, LIMING AND REACIDIFICATION ON MACROPHY TE DEVELOPMENT, WATER QUALITY AND SEDIMENT CHARACTERISTICS OF SOFT-WATER LAKES
}

\author{
JaN G.M. Roelofs ${ }^{1}$, Alfons J.P. SMOLders ${ }^{1}$, TOR-ERIK BRANDRUd ${ }^{2}$ AND Roland \\ BOBBINK $^{\mathrm{I}}$ \\ ${ }^{2}$ Environmental Biology, Department of Ecology, University of Nijmegen, Toemooiveld, 6525 ED Nijmegen, \\ The Netherlands. \\ ${ }^{2}$ Norwegian Institute for Water Research NIVA, P.O. Box 173, Kjelsås, N-0411 Oslo, Nonway.
}

\begin{abstract}
Rapid expansion of Juncus bulbosus $\mathbf{L}$. and the concomitant suppression of isoetid plant species has often been observed in acidifying soft water lakes in Western Europe. Experimental studies have shown that this mass development of J.bulbosus was caused by changes in the carbon and nitrogen budgets in these ecosystems. Acidification leads to temporarily strongly increased carbon dioxide $\left(\mathrm{CO}_{2}\right)$ levels in the slightly calcareous sediment and to accumulation of ammonium as a result of a reduced nitrification rate in acidifying waters. Many acidifying Scandinavian soft water lakes, however, have a well developed macrophyte vegetation. It is suggested that this is related with the non-calcareous sediments of these lakes. After liming, however, mass development of J.bulbosus and/or Sphagnum spec. has been observed in Swedish and S.W. Norwegian lakes. From field experiments it has become clear that part of the lime is deposited on the sediments leading to an increase of mineralisation rates, $\mathrm{CO}_{2}$ production, sediment pore water levels of phosphate and ammonium and to a decrease of the nitrate concentrations in the sediment. These changes have been earlier observed in acidifying West European waters. Rooted species like J.bulbosus can only benefit from the higher nutrient levels in the sediment when the $\mathrm{CO}_{2}$ level of the water layer is relatively high as this species is adapted to leaf carbon uptake. It is demonstrated that gradual reacidification by the acid water from the catchments and the increased flux of carbonic acid from the limed sediments to the overlying water leads to increased $\mathrm{CO}_{2}$ levels in the water layer of the limed lakes already a few months after liming.
\end{abstract}

Key words: Water acidification, Liming, Re-acidification, Carbon dioxide, Aquatic macrophytes, Isoetides, Juncus bulbosus.

\section{Introduction}

Luxurious growth of Juncus bulbosus L. and the concomitant suppression of isoetid species, such as Lobelia dortmanna L., Littorella uniflora (L.) Aschers. and Isoetes species is often observed in acidified, shallow soft water lakes in the Netherlands and other Western European countries (Van Dam and Kooyman-van Blokland, 1978; Roelofs, 1983) Hultberg and Grahn (1975) and Grahn (1977) observed also an increased growth of submerged Sphagnum and J.bulbosus in acidified Swedish lakes. Alenäs et al. (1991) concluded that increased Sphagnum and Maugeotia production could be attributed to reacidification after liming. Experimental studies have shown that the mass expansion of J.bulbosus has been caused by changes in the carbon and nitrogen budgets in these ecosystems. Acidification leads to temporarily strongly increased carbon dioxide levels in the slightly calcareous sediments and to accumulation of ammonium owing to atmospheric deposition and a reduced nitrification rate in the acidified waters (Roelofs $e t$ al, 1984 Schuurkes et al., 1987). The luxurious growth stopped after the depletion of the

Water, Air and Soil Pollution 85: 967-972, 1995.

(C) 1995 Kluwer Academic Publishers. Printed in the Netherlands. 
carbonate/bicarbonate pool in the sediment (Roelofs, 1983). Also Svedäng $(1990,1992)$ found a correlation between the increased $\mathrm{CO}_{2}$ levels in the water layer and J.bulbosus growth in a Swedish lake.

Contrary to soft water lakes in central Europe, isoetid plants are still very common in acidified Scandinavian lakes. Isoetid plants such as L.uniflora are known to be very acid resistant (Maessen et al., 1992; Roelofs et al., 1994). Therefore it seems likely that the mass development of J.bulbosus, as a result of the strong increase of $\mathrm{CO}_{2}$ levels in the water layer, is responsible for the disappearance of most of the (slow growing) plant species in shallow acidified waters in the Netherlands.

In contrast to most isoetid species, J.bulbosus uses $\mathrm{CO}_{2}$ from the water layer for photosynthesis (Roelofs et al., 1984) and therefore profits from increased carbon dioxide levels in the water layer. Reports of mass development of J.bulbosus after acidification of Scandinavian lakes, however, are relatively scarce. Roelofs et al. (1994) did not find increased growth of J.bulbosus in acidified S.W. Norwegian lakes and they concluded that in contrast to the slightly calcareous shallow waters in the Netherlands, acidification of lakes with non-calcareous sediments, such as in SW Norway ones, does not lead to a sufficient increase of carbon dioxide levels in the water layer and even to a lowering of the nutient availability in the sediments (Hultberg and Grahn 1975). During the last years, however, there are observations of extremely dense J.bulbosus growth along the littoral zone of lakes in SW Norway. In some lakes this zone (down to $4 \mathrm{~m}$ depth) is completely filled with J.bulbosus. These gigantic belts of J.bulbosus lead to the disappearance of almost all other plant species. All lakes with this massive expansion of J.bulbosus have in common that they have been limed during the last 3-6 years. Similar observations have been made for some limed Swedish lakes (H. Hultberg; personal communication).

To investigate whether liming leads to increased levels of nutrients in the sediment pore water and a increased flux of $\mathrm{CO}_{2}$ to the waterlayer, wich could be an explanation for the mass development of J.bulbosus, the water quality and the pore water chemistry of six limed (formerly acidified) lakes with strongly increased J.bulbosus growth and five acidified (reference lakes) were studied in 1993 and 1994. Furthermore vegetation analysis have been made and the net flux of $\mathrm{CO}_{2}$ and total inorganic carbon from the sediment to the water layer were estimated in one reference and two limed lakes.

All investigated lakes are situated in the Dalane region (SE Rogaland) in the south-western part of Norway. It is a region with Precambrium bedrock of a homogenous, very nutrient-poor anorthosite type (Holtedahl, 1960). The buffer capacity of the sediments is very low and nowadays most lakes and rivers have been acidified. To counteract the negative effects of acidification many of the lakes have been annually limed. All study sites are located in the macrophyte dominated relatively shallow littoral parts of the lakes (see Roelofs et al. 1994 for the exact location).

\section{Material and methods}

Water and pore water samples were collected and $\mathrm{pH}$, alkalinity, and acidity were determined. Carbon dioxide and bicarbonate were calculated from the acidity and alkalinity respectively, after correction for $\mathrm{pH}$. From the remaining samples $100 \mathrm{ml}$ was collected in polyethylene bottles, fixated with citric acid and stored at $-20^{\circ} \mathrm{C}$. Water samples were 
collected in July 1993, July 1994 and October 1994. Sediment pore water samples were collected in July 1993.

Polyethylene containers (10 1., surface area of $0.12 \mathrm{~m}^{-2}$ ) were carefully placed upon the sediment of a reference lake (lake Haptatjörn) and two limed lakes (Heimrevatn and Gjuvatn) in July 1994. In every lake, three enclosures were placed. Immediately after the start of the experiment, water samples were obtained with a $50 \mathrm{ml}$ syringe and a needle. Sampling was repeated after 10 months (May 1995). The samples were analysed for total inorganic carbon (TIC) and $\mathrm{CO}_{2}$ as described by Roelofs et al. (1994).

All chemical analyses were carried out following Roelofs et al. (1994). Statistical analyses between the reference lakes and the limed lakes were done with non-parametric Wilcoxontests (Sokal and Rohlf, 1981).

Plant material was collected at one to three sampling sites in each lake. Four times 0.04 $\mathrm{m}^{-2}$ of vegetation, including roots, were collected randomly, using a framework. After being washed thoroughly, shoots and roots were seperated and dried at $70^{\circ} \mathrm{C}$ for $24 \mathrm{~h}$ after which the dry weight was measured.

\section{Results}

Bicarbonate and $\mathrm{CO}_{2}$ levels in the sediment pore water of the limed lakes were much higher than in that of the reference lakes. Although the lakes were limed with calcium carbonate, not the calcium concentrations but the iron and manganese levels had increased in the pore water of limed lakes. The phosphate levels were 2.6 times higher in the sediment pore water of the limed lakes, while the nitrate levels were much lower. Both the ammonium and the total inorganic nitrogen levels in the sediments of the limed lakes were much higher than in the reference lakes (Table I).

In July, a few weeks after liming, the acidity and $\mathrm{CO}_{2}$ levels were much lower in the limed lakes than in the reference lakes (Table II). In October, however, the acidity and carbon dioxide levels had strongly increased in the limed lakes and were considerably higher compared with the reference lakes (Table II).

Figures $1 \mathrm{a}, 1 \mathrm{~b}$ show the increase in $\mathrm{CO}_{2}$ and total inorganic carbon (TIC) in the containers that were placed in the reference lake (Haptatjörn) and the two limed lakes (Heimrevatn and Gjuvatn). The results clearly show a strongly increased flux of carbon dioxide and TIC from the sediment to the water layer in the limed lakes compared with the reference lakes in this time span.

The differences in macrophyte biomass between the limed and the reference lakes were spectacular; the biomass of $1156 \mathrm{~g} \mathrm{DW} \mathrm{m}^{-2}$ in the limed lakes can be almost completely attributed to J.bulbosus. In the reference lakes the mean total biomass was $84 \mathrm{~g} \mathrm{DW} \mathrm{m}^{-2}$. The biomass of the other macrophytes was lower in the limed lakes than in the reference lakes (Table III).

Shoot to root ratios are usually low in oligotrophic waters. In the limed lakes however the shoot to root ratios of all species were considerably higher than in the reference lakes (Table III). These differences were the result of both the higher shoot biomass and lower root biomass in the limed lakes. The differences in shoot to root ratio of the J.bulbosus vegetations between the limed (2.9) and reference lakes (22) was enormous (Table III). These differences can mainly be ascribed to the much higher shoot biomass in the limed lakes. 


\section{TABLE I}

A comparison between the physical and chemical ( $\mu$ mol.1-1) properties of sediment pore water of 6 limed and 5 reference lakes in SW Norway. Statistical differences were estimates according to Wilcoxon: -, not significant; ${ }^{* *}, \mathrm{p}<0.01 ;{ }^{* * *} \mathrm{P}<0,005 ; \mathrm{n}=$ number of sampling sites.

\begin{tabular}{lccc}
\hline & $\begin{array}{l}\text { Reference lakes } \\
\mathrm{n}=10 \\
\text { mean }\end{array}$ & $\begin{array}{l}\text { Limed lakes } \\
\mathrm{n}=6 \\
\text { mean }\end{array}$ & Wilc. Test \\
\hline $\mathrm{pH}$ & 5.5 & 6.2 & $* *$ \\
Bicarbonate & 118 & 1245 & $* *$ \\
Carbon dioxide & 526 & 1506 & $* *$ \\
Ammonium & 5.1 & 77 & $* *$ \\
Nitrate & 13 & 1.7 & - \\
Phosphate & 0.10 & 0.26 & $* *$ \\
Calcium & 94 & 163 & $* *$ \\
Iron & 8.3 & 771 & $* *$ \\
Manganese & 2.1 & 56 & - \\
Redox (mV) & 258 & 50 & \\
Org. matter & 1 ) & 26 & \\
1) $\%$ of dry sediment & 15 & &
\end{tabular}

\section{Discussion}

It seems obvious that liming is responsible for the luxurious growth of J.bulbosus considering the low biomass of this species in the reference lakes compared to the limed ones. The unlimed and limed lakes are situated in the same area with the same bedrock and a comparable organic matter content of the sediments (Table 1). Liming of the lakes resulted in changes in the sediment chemistry and C-economy of at least the shallower parts of the lakes. It is likely that these changes caused the observed luxurious growth of J.bulbosus in the limed lakes.

\section{TABLE II}

Comparison between the acidity ( $\mu \mathrm{eq} \mathrm{I}^{-1}$ )and carbon dioxide $\left(\mu \mathrm{mol} \mathrm{I}^{-1}\right)$ levels of the water layer of five unlimed (reference) and five limed lakes, 2 weeks and 16 weeks after liming in July 1994. SD is given in parentheses.

\begin{tabular}{lrrrr}
\hline & & Reference & & Limed \\
& Acidity & $\mathrm{CO}_{2}$ & Acidity & $\mathrm{CO}_{2}$ \\
\hline 2 wks & 109 & 92 & 38 & 36 \\
$($ July $)$ & $(25)$ & $(22)$ & $(16)$ & $(16)$ \\
& & & & \\
16 wks & 135 & 127 & 185 & 183 \\
(October) & $(25)$ & $(21)$ & $(23)$ & $(23)$ \\
\hline
\end{tabular}




\section{TABLE III}

The total macrophyte biomass ( $\mathrm{g} . \mathrm{DW} \mathrm{m} \mathrm{m}^{-2}$ ) and the biomass and the shoot to root ratios (based upon dry weight) of the individual plant species in six limed and five reference lakes in SW Norway. Statistical differences (Wilcoxon-test): NS, not significant; *, $\mathrm{p}<0.05 ; * *, \mathrm{p}<0.01 ; * * *, \mathrm{p}<0.001, \mathrm{n}=$ number of sampling sites.

\begin{tabular}{|c|c|c|c|c|c|}
\hline & Biomass & & & Root/shoo & $t$ rates \\
\hline & $\mathrm{n}=5$ & $n=6$ & & $\mathrm{n}=5$ & $\mathrm{n}=6$ \\
\hline$\overline{\text { total }}$ & 84 & 1156 & $* * *$ & - & \\
\hline Littorella uniflora & 48 & 12 & $*$ & 0.9 & $3.4^{*}$ \\
\hline Lobelia dortmanna & 60 & 19 & NS & 1.0 & $5.1 * *$ \\
\hline Isoetes spec. & 57 & 15 & $*$ & - & -- \\
\hline Juncus bulbosus & 58 & 1130 & $* *$ & 2.9 & $22.0^{* *}$ \\
\hline
\end{tabular}
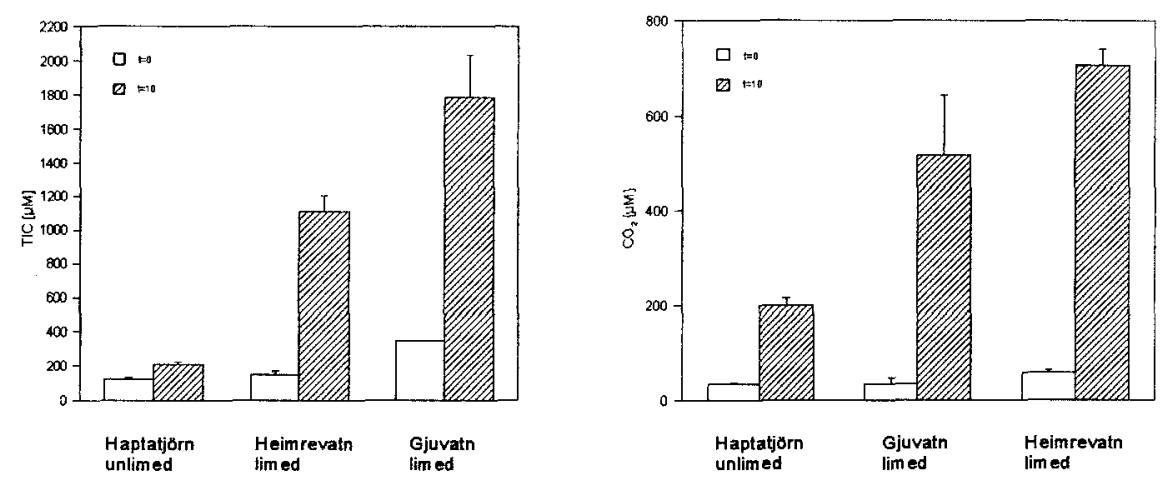

Figure 1. The Total Inorganic Carbon (TIC) and $\mathrm{CO}_{2}$ concentrations of the water layer in enclosures placed on unlimed and limed sediments at $\mathrm{t}=0$ (July 1994) and $\mathrm{t}=10$ months (May 1995). Organic content of the sediments: Haptatjörn (unlimed) $29 \%$; Heimrevatn (limed) $17 \%$; Gjuvatn (limed) $22 \%$. Vertical bars indicated SD. $\mathrm{N}=3$.

After liming the concentrations of carbon dioxide, phosphorus and ammonium increased strongly in the sediment pore water. J.bulbosus is known to be adapted to ammonium uptake (Schuurkes et al., 1987). In the Netherlands luxurious growth of J.bulbosus normally occurs in waters with ammonium accumulation. The ammonium levels are rather low in the oxidative sediments of the SW Norwegian lakes while nitrate is the predominant nitrogen form. After liming nitrate levels strongly decreased, whereas ammonium levels showed a more than 10 -fold increase. We suggest that liming leads to an increased mineralisation of organic matter. It is well known that a high bicarbonate alkalinity in the sediment stimulates decomposition processes by the neutralisation of acids produced within the detritus particles during mineralisation (Kok and Van de Laar, 1991). As a result of the increased mineralisation processes nitrogen and phosphorus levels are 
increased while the redox potential decreases strongly. The decreased redox potential resulted in decreased nitrification, i.e. decreased nitrate levels and iron reduction which is reflected in the strongly enhanced iron levels in sediment pore water samples of the limed lakes. Increased iron reduction generally leads to the mobilisation of phosphate from iron(III)-phosphate complexes (Patrick et al., 1973, Smolders and Roelofs, 1993). It is concluded that liming an oligotropic lake sediment leads to an increased mineralisation and decreased redox potential and therefore to a strongly increased availibility of phosphate and above all ammonium in sediment pore water, which particularly favours J.bulbosus.

Furthermore the C-economy of the water layer was strongly influenced . Liming as such leads to an increased $\mathrm{pH}$ value and to decreased levels of carbon dioxide in the water layer, as is demonstrated by the summer values obtained in July just after the lakes had been limed. Gradually reacidification by the acid water from the catchments of these lakes (Table II) and the increased flux of carbonic acid from the limed sediments to the overlying water led to substantially increased carbon dioxide levels (Figure 1).

It can be concluded that J.bulbosus can reach extremely high masses in the limed lakes because of the increased availability of nutrients (ammonium and phosphorus) in the sediment and the increased carbon dioxide levels in the water layer after reacidification of the limed lakes.

\section{Acknowledgements}

The authors wish to thank J.M.A. Hendriks, M. Mjelde, B.G.P. Paffen, R. Nijboer and Y. de Wit for their practical assistance in the field.

\section{References}

Alenäs, I., Andersson, B.I., Hultberg, H. and Rosemari, A.: 1991, Water, Air and Soil Pollut. 59, 55-77.

Grahn, O.: 1977, Water Air and Soil Pollut. 7, 295-305.

Holtedahl, O. (Editor) : 1960, Geology of Norway. Norges Geol. Unders. 208, 1-540.

Hultberg,H.and Grahn, O.:1975, Effects of acid precipitation on macrophytes in oligotrophic Swedish lakes. Intemat. Assoc. Great Lakes Res 1:208-217.

Kok, C.J. and van de Laar, B.J.: 1991, Verh. Int. Verein Limnol. 24, 2689-2692.

Maessen, M. Roelofs, J.G.M., Bellemakers, M.J.S. and Verheggen, G.M.: 1992, A quat. Bot. 43, 115-127.

Patrick, W.H., Gotoh, S. and Williams, B.G.: 1973, Science 179, 564- 565.

Roelofs, J.G.M.: 1983, A quat. Bot. 17, 139-155.

Roelofs, J.G.M., Brandrud, T.E. and Smolders, A.J.P.: 1994, A quat. Bot. 48, 187-202.

Roelofs, J.G.M., Schuurkes, J.A.A.R. and Smits, A.J.M.: 1984, A quat. Bot. 18, 389-411.

Schuurkes, J.A.A.R., Elbers, M.A., Gudden, J.J.F. and Roelofs, J.G.M.: 1987, A quat. Bot. 28, 19-226.

Smolders, A.J.P. and Roelofs, J.G.M.: 1993, Aquat. Bot. 46, 247-253.

Sokal, R.R. and Rohlf, F.J.: 1981, Biometry. Freeman, San Francisco, CA, 859 pp.

Svedäng, M.U.: 1990, A quat. Bot. 37, 123-138.

Svedang, M.U.: 1992, A quat.Bot. 42, 231-240.

Van Dam,H. and Kooyman van Blokland, H.: 1978, Int. Rev. Ges. Hydrobiol. 63, 587-607. 